Joana C.M. Monteiro

\title{
Effects of Natural Resource Abundance and Neighborhood Violence on Economic Development
}

Thesis presented to the Postgraduate Program in Economics of the Departamento de Economia, PUC-Rio as partial fulfillment of the requirements for the degree of Doutor em Economia

Advisor: Prof. Claudio Ferraz 


\author{
Joana C.M. Monteiro
}

\title{
Effects of Natural Resource Abundance and Neighborhood Violence on Economic \\ Development
}

Thesis presented to the Postgraduate Program in Economics of the Departamento de Economia, PUC-Rio as partial fulfillment of the requirements for the degree of Doutor em Economia. Approved by the following commission:

\author{
Prof. Claudio Ferraz \\ Advisor \\ Departamento de Economia - PUC-Rio
}

Prof. João Manuel Pinho de Mello

Departamento de Economia - PUC-Rio

Prof. Rodrigo Reis Soares

Departamento de Economia - PUC-Rio

Prof. Bernardo Mueller

Departamento de Economia - UNB

Prof. Ricardo de Abreu Madeira

Departamento de Economia - USP

Prof. Mônica Herz

Coordinator of the Centro de Ciências Sociais - PUC-Rio

Rio de Janeiro - December 6, 2010 
All rights reserved.

\section{Joana C.M. Monteiro}

Joana Monteiro holds a BA in economics from the Federal University of Rio de Janeiro (UFRJ), a MA in economics from the Catholic University of Rio de Janeiro (PUC-Rio) and now a Ph.D in economics from PUC-Rio. During her Ph.D., she visited Harvard University as a research fellow at the Center for International Development. Joana does research on economic development and has performed studies on different topics such as informality, labor market, natural resources, political economy, violence and education. Before enrolling in the Ph.D. program, Joana worked at DAI Brazil, a Brazilian subsidiary of Development Alternatives, Inc. (www.dai.com). During three years at DAI Brazil, she had the opportunity to participate in projects in different parts of Brazil, Mexico and Guatemala for clients such as USAID, IADB, local governments and public institutions.

Bibliographic data

Monteiro, Joana C.M.

Effects of Natural Resource Abundance and Neighborhood Violence on Economic Development / Joana C.M. Monteiro ; advisor: Claudio Ferraz. - 2010.

141 f. : il. ; $30 \mathrm{~cm}$

Tese (Doutorado em Economia)-Pontifícia Universidade Católica do Rio de Janeiro, Rio de Janeiro, 2010.

Inclui bibliografia

1. Economia - Teses. 2. Responsabilização política; recursos naturais; violência; desempenho escolar. I. Ferraz, Claudio. II. Pontifícia Universidade Católica do Rio de Janeiro. Departamento de Economia. III. Título. 


\section{Acknowledgments}

Muitas pessoas me ajudaram e me apoiaram nos últimos quatro anos, às quais expresso aqui meus agradecimentos.

Essa tese conclui meu ciclo de aprendizado no Departamento de Economia da PUC-Rio. Essa escola me ensinou a destrinchar números, a construir argumentos e a não fazer afirmações sem fundamentos. Saio da PUC convencida que os indivíduos são movidos a incentivos e que o objeto número um das políticas públicas deve ser a igualdade de oportunidades. Obrigada a todos os professores que contribuíram para a minha formação. Em especial, agradeço ao meu orientador, Claudio Ferraz, pela dedicação, atenção e estímulo ao longo dos últimos anos, e aos professores Juliano Assunção e Rodrigo Soares. Meus amigos de doutorado também foram essenciais durante esse período. Obrigada Arnildo, Daniela, Daniel, Fernando, Hamilton, Isabelle, Marcelo e Rudi pela constante troca de idéias e angústias. O Rudi, meu co-autor no terceiro capítulo desta tese, foi um grande amigo ao longo desses anos.

Ao professor Filipe Campante, devo um especial obrigado por ter tornado possível minha estadia em Harvard e por ter me recebido para inúmeras conversas. A experiência nos EUA me mostrou um novo mundo e me fez conhecer inúmeras pessoas que buscam incansavelmente o conhecimento com o principal objetivo de entender o mundo.

Quero dizer obrigada ao André Urani e ao Paulo Ferraz, dois entusiastas do Rio de Janeiro, que me incentivaram a estudar os problemas e contradições da região em que nasci.

Por fim, agradeço a minha família. Sem meus pais, Ana e Ascânio, que sempre me ensinaram a buscar os meus sonhos, a estudar e lutar pelo que eu acredito, jamais chegaria até aqui. Laura, minha irmã, nunca deixou de estar ao meu lado e me dar muito carinho. O Rafael, meu marido e grande companheiro, tornou, com sua constante alegria, apoio e incentivo, meu doutorado uma tarefa bem menos árdua, mais prazerosa e possível. Meus últimos agradecimentos são para meu filho, que começou a me acompanhar nos últimos meses e me fez terminar a tese o mais rápido possível. Miguel já nasce mostrando ser compreensivo e companheiro e me dando forças para usar meu estudo para ajudar a construir um país sem violência, pobreza e desigualdades. Um país onde ele possa viver em paz e ser feliz. 


\section{Abstract}

Monteiro, Joana C.M.; Ferraz, Claudio (Advisor). Effects of Natural Resource Abundance and Neighborhood Violence on Economic Development. Rio de Janeiro, 2010. 141p. Tese de Doutorado Departamento de Economia, Pontifícia Universidade Católica do Rio de Janeiro.

This thesis is comprised of three articles. The first two chapters study the effects of natural resource abundance on economic development by analyzing Brazil's offshore oil boom and the distribution of royalties to municipalities. In the first chapter, we examine the impact of this oil boom on local economies. We show that oil production has little economic impact on the municipalities, other than in the public sector. By far, the most important effect is on the number of public employees, which increased a great deal from 1997 to 2006. Few improvements were found on health and educational services. The second chapter analyzes oil effects on local politics. We show evidence that oil does not make leaders unaccountable and that a democratic system is crucial to avoid the negative effects of resource abundance. Our results indicate that, although oil windfall creates a large incumbency advantage in the short run, voters reward incumbents by reappointing them to office as long as they are not completely informed of the size of the extraordinary revenue and see increases in public employment as an indication of mayor's ability. In the medium run, as information about the resources increases and a larger public sector does not translate into more public goods and services, citizens oust the incumbent and select new candidates. The third chapter investigates a different subject. We analyze the relationship between neighborhood violence and school achievement, by exploring time and geographical variation in Rio de Janeiro's drug battles. We find that schools close to areas that experience more variation in armed conflicts over time perform worse in standardized math exams, while no significant effect is found on language exams. Violent events are also associated with an increase in grade repetition and dropout for 5th graders. In terms of mobility across schools, we find no significant effects of violence on students' transfers and new admissions during the school year. We also discuss the mechanisms that can explain these results and provide evidence that violence is associated with an increase in teacher absenteeism.

\section{Keywords}

Political accountability; natural resources; oil; neighborhood violence; school achievement. 


\section{Resumo}

Monteiro, Joana C.M.; Ferraz, Claudio (Orientador). Efeitos da Abundância de Recursos Naturais e da Violência Local sobre Desenvolvimento Econômico. Rio de Janeiro, 2010. 141p. Tese de Doutorado - Departamento de Economia, Pontifícia Universidade Católica do Rio de Janeiro.

Essa tese é composta por três artigos. Os dois primeiros estudam os efeitos da abundância de recursos naturais através da análise do recente boom de petróleo no Brasil e a distribuição de royalties para os municípios. No primeiro capítulo, estuda-se os efeitos do boom de petróleo sobre a economia local. Mostra-se que os efeitos da produção de petróleo são pequenos, limitando-se ao impacto sobre o setor público. O maior impacto encontrado é sobre o número de funcionários públicos municipais, que aumenta consideravelmente entre 1997 e 2006. São encontrados efeitos modestos sobre a oferta de educação e saúde. O segundo capítulo analisa os efeitos do royalties de petróleo sobre a política local. Os royalties aumentam a probabilidade de reeleição dos prefeitos na primeira eleição que sucede o boom de receitas, mas essa vantagem não persiste nas eleições seguintes. Os resultados são consistentes com um processo de aprendizado por parte dos eleitores, que somente reconduzem os prefeitos ao poder quando têm conhecimento limitado sobre o choque positivo de receitas e interpretam o aumento de funcionários públicos como um sinal de habilidade do prefeito. Contudo, os resultados indicam que a abundância de recursos não acabou com a responsabilização dos prefeitos e que um sistema democrático é crucial para restringir o uso irresponsável desses recursos. O terceiro capítulo investiga um outro tema: a relação entre violência local e desempenho escolar. Explora-se a variação no espaço e no tempo do conflito de drogas no Rio de Janeiro para entender o impacto desses conflitos sobre as escolas municipais. Encontra-se que as áreas que sofreram mais variação de conflitos armados ao longo do tempo têm um desempenho inferior em testes padronizados de matemática. A exposição aos conflitos também é associada a aumento na reprovação e do abandono de alunos do quinto ano do ensino fundamental. Discute-se ainda os canais que podem explicar a piora do desempenho e identifica-se que violência está associada a maior ausência de professores nas escolas.

\section{Palavras-chave}

Responsabilização política; recursos naturais; violência; desempenho escolar. 


\section{Contents}

1 Brazil's Oil Boom and its Effects on Local Economies 1

1.1 Introduction

1.2 Institutional Framework 4

1.3 Empirical Strategy 6

$\begin{array}{lll}1.4 & \text { Data } & 9\end{array}$

$\begin{array}{ll}1.5 & \text { Empirical Results } \\ 1.6 & 12\end{array}$

$\begin{array}{ll}1.6 \text { Conclusion } & 21\end{array}$

2 Does Oil Make Leaders Unaccountable? 39

$\begin{array}{lll}2.1 & \text { Introduction } & 39\end{array}$

2.2 Oil Royalties and Malfeasance: the case of Campos dos Goytacazes 42

2.3 Theoretical Framework 43

2.4 Empirical Strategy and Data 48

$\begin{array}{lll}2.5 & \text { Empirical Results } & 50\end{array}$

$\begin{array}{lll}2.6 \text { Conclusion } & 60\end{array}$

3 Neighborhood Violence and School Achievement: Evidence from Rio de Janeiro's Drug Battles $\quad 74$

3.1 Introduction $\quad 74$

$\begin{array}{lll}3.2 & \text { Institutional Background } & 76\end{array}$

$\begin{array}{lll}3.3 \text { Data } & 81\end{array}$

3.4 Conceptual Framework 86

3.5 Empirical Strategy 90

$\begin{array}{lll}3.6 & \text { Results } & 94\end{array}$

$\begin{array}{llr}3.7 & \text { Robustness } & 98\end{array}$

$\begin{array}{lll}3.8 \text { Conclusion } & 100\end{array}$

$\begin{array}{lr}\text { A Royalty Rule } & 126\end{array}$

B Oil Data $r$

$\begin{array}{ll}\text { B.1 Oil output } & 129\end{array}$

B.2 Royalty payments 130

B.3 Other data 132

$\begin{array}{ll}\text { C Model Appendix } & 134\end{array}$

$\begin{array}{ll}\text { C.1 Posterior variance } & 134\end{array}$

C.2 Partial effects on rents: 134

C.3 Partial effects on reelection probability 134

D Coding Disque-Denuncia Reports $\quad 136$

$\begin{array}{ll}\text { E Triggers of Drug Battles } & 140\end{array}$ 


\section{List of Figures}

1.1 Oil Field Output in 2008 by Year of Field Discovery 35

1.2 Oil Production 1994-2008 36

1.3 Orthogonal and Parallel Lines on Rio de Janeiro Coast 36

1.4 Location of Producing and Non-producing Municipalities 37

1.5 Municipal Employees in Oil Producing and Non-producing Municipalities 1997-2008 38

2.1 Royalty Payments to Brazilian Municipalities 1994-2008 70

2.2 Number of Tenured and Non-tenured Employees 1997-2008 71

2.3 Actual and Predicted Royalties 72

2.4 Newspaper Coverage $\quad 73$

3.1 Slum and School Distribution 115

3.2 Number of Days with Reports about Gunfight 2004-2009 116

3.3 Number of Days with Reports about Gunfight per Year in Selected Slums 2004-2009 117

3.4 Homicides and Number of Days with Conflicts 2004-2009 118

3.5 Homicides and Number of Days with Conflicts per AISP 119 